\title{
Franci AvsEC* \\ Legal Framework of Agricultural Land/Holding Succession and Acquisition in Slovenia ${ }^{* *}$
}

Abstract

Agricultural land legislation in Slovenia contains extensive special provisions that directly regulate the legal transfer of agricultural land and holdings inter vivos and mortis causa, including inheritance. Additionally, some measures within the common agricultural policy (such as financial support for the takeover of farms by young farmers) and tax policies (exemptions) provide incentives or alleviations for certain legal transactions involving the transfer of agricultural land and holdings. Among special provisions on the transfer of agricultural land and holdings, those relating to a statutory preemption right and a statutory priority right to lease agricultural land have the longest continuity (from the late 1950s). The holders of these priority rights must meet certain requirements and range in several priority classes. At first, agricultural organisations as legal persons bad better priority rights than farmers. In 1990, the priority order was reversed by placing individual farmers before legal persons, individual agricultural entrepreneurs, and the National Agricultural Land and Forest Fund (NALFF). In 1973, the agricultural land legislation prohibited the division of certain middle-sized family farms (protected farms) through inheritance (mortis causa) and later (1986), also inter vivos, (with certain exceptions). The Agricultural Land Act and the Forests Act also restrict the division of certain agricultural or forest land plots. The draft acts of 2019 and 2020 prepared by the Ministry of Agriculture foresee important changes of the agricultural land policy, including the priority order between the statutory preemption rights and the removal of a general restriction on the division of protected farms inter vivos.

Keywords: agricultural land legislation, protected farms, Slovenia.

\section{Introduction}

In Slovenia, the transfer of agricultural land and holdings inter vivos and mortis causa is regulated by a complex set of special rules within the agricultural land legislation, which partly supplement and derogate general provisions of property, obligation, and succession law. General provisions on legal transfer of property in Slovenia are systematically codified in the Property Code (PC), ${ }^{1}$ the Obligations Code (OC), ${ }^{2}$ and the Inheritance Act (IA). ${ }^{3}$

Franci Avsec: Legal Framework of Agricultural Land/Holding Succession and Acquisition in Slovenia. Journal of Agricultural and Environmental Law ISSN 1788-6171, 2021 Vol. XVI No. 30 pp. 24-39, https://doi.org/10.21029/JAEL.2021.30.24

* Dr.iur., Associate Professor, University of Novo mesto, Faculty of Economics and Informatics, Novo mesto, Slovenia, e-mail: franci.avsec@siol.net, ORCID: 0000-0002-92942235.

** The research of this article was supported by the Ferenc Mádl Institute of Comparative Law.

1 Stvarnopravni zakonik 2002, with subsequent amendments.

2 Obligacijski zakonik 2001, with subsequent amendments.

${ }^{3}$ Zakon o dedovanju 1976, with subsequent amendments. 
The most important special provisions for the transfer of agricultural land, forests, and agricultural holdings are included in four pieces of Slovenian agricultural land legislation.

The Agricultural Land Act (ALA) ${ }^{4}$ defines agricultural land as land that is suitable for agricultural production and is designated as agricultural land in spatial planning documents. The legal transfer of agricultural land, forests, and agricultural holdings is defined as the acquisition of ownership rights on agricultural land, forests, and agricultural holdings through legal transactions inter vivos, and in some other cases, regulated by this Act (Art. 17(1); in this regard, the ALA mentions contracts of donations mortis causa). Interestingly, the narrow definition of legal transfers is limited to legal transactions of the translative type (where the ownership right is transferred in its entirety). The definition of legal transfers in the ALA does not include constitutive legal transfers, where only one essential constituent part of the ownership right - for instance, the right of use - is transferred. The provisions of the ALA on legal transfer, therefore, apply to contracts transferring ownership rights, such as sales contracts, ${ }^{5}$ exchange contracts, ${ }^{6}$ donation contracts, ${ }^{7}$ delivery contracts, ${ }^{8}$ lifelong maintenance contracts, ${ }^{9}$ and subsistence contracts. ${ }^{10}$ Indeed, the ALA regulates, in a separate chapter, the contractual lease of agricultural land without formally including lease contracts in the notion of legal transfers. Other legal transactions where the right of use as an obligation law right (for instance, right of use originating from loan for use contracts) or a real right (right in rem, for instance, usufruct on agricultural land or forest) is established or transferred, are completely out of the scope of the ALA. One would expect a wider scope of the agricultural land legislation with regard to the relevant provisions of the Slovenian Constitution, ${ }^{11}$ according to which, the law establishes special conditions for land utilisation to ensure its proper use, while the agricultural land enjoys special protection (the first and the second paragraph of Article $70)$.

The Forests Act $(\mathrm{FA})^{12}$ contains provisions on silviculture, protection, harvesting, and the use of forests to provide the sustainable, close-to-nature management of forests, which also tackles the legal transfer of forests directly (such as statutory preemption right) or indirectly (for instance, prohibited division of plots).

The Inheritance of Agricultural Holdings Act (IAHA) ${ }^{13}$ contains special succession rules for certain agricultural holdings (protected farms). According to these general succession rules, inheritance may be based on the last will of the deceased (testamentary inheritance), or, if there is no will or the will is not valid, on the provisions of inheritance legislation (intestate inheritance).

\footnotetext{
${ }^{4}$ Zakon o kmetijskih zemljiščih, 1996, with subsequent amendments.

${ }^{5}$ Obligacijski zakonik 2001, Art. 435-527.

${ }^{6}$ Ibid. Art. 528-529.

${ }^{7}$ Ibid. Art. 533-545.

8 Ibid. Art. 546-556.

${ }^{9}$ Ibid. Art. 557-563.

${ }^{10}$ Ibid. Art. 564-568.

${ }_{11}$ Ustava Republike Slovenije 1991, with subsequent amendments.

12 Zakon o gozdovih 1993, with subsequent amendments.

${ }^{13}$ Zakon o dedovanju kmetijskih gospodarstev 1995, with subsequent amendments.
} 
Slovenian law does not allow, in principle, inheritance contracts: contracts by which someone leaves their estate to other contractors, disposes of an expected inheritance to someone who is still alive, undertakes to determine something in their will or revoke it are null and void (Art. 103-105 of the IA). The only exemption from this prohibition is the agreement on renunciation of a descendant to inherit from an ancestor or of one spouse to inherit from the other spouse (Art. 138-140 of the IA).

During privatisation, socially owned agricultural land and forests were transferred to the State, which had established a national agricultural land and forests fund through a special act (National of Agricultural Land and Forests Fund Act, NALFFA). ${ }^{14}$ The State-owned agricultural land that was not restored to former owners during denationalisation process was leased out by the National Fund primarily to privatised enterprises as former users and, subordinately, to other lessees (individual farmers and legal persons dealing with agricultural activity).

The legal transfer of agricultural land, forests, and agricultural holdings is at least influenced by some measures of tax policy (exemptions and alleviations) and (common) agricultural policy (for instance, financial support for young farmers taking over a farm). In the next section, the paper analyses the special provisions on the legal transfer of agricultural land, forests, and agricultural holdings inter vivos. The statutory preemption right and agricultural land leases will also be outlined in more detail.

The paper analyses the present legislation in force (de le lata) and the most important proposals from two draft acts prepared by the Ministry of Agriculture in 2019 and 2020 to amend the present regulation (de lege ferenda). The Draft Act of 2019 contained proposals to amend and supplement several acts in the field of agricultural land policy. ${ }^{15}$ Following the results of the public consultation on the Draft Act of 2019, the Ministry of Agriculture published, in November 2020, a new Draft Act with a narrower scope and more moderate legislative changes for a public discussion. ${ }^{16}$

Special rules on the legal transfer of agricultural land, forests, and holdings, inter vivos cannot be understood without taking into account the regulation of inheritance, including special succession rules for protected farms. The third section, therefore, outlines some basic general and special succession rules in agriculture. The fourth section briefly mentions policy measures that stimulate certain legal transactions for agricultural land and holdings. The fifth section of the paper deals with the acquisition of agricultural land by legal persons and the sixth section contains concluding findings and remarks.

\footnotetext{
14 Zakon o Skladu kmetijskih zemljišč in gozdov Republike Slovenije 1993, with subsequent amendments.

15 Osnutek Zakona o spremembah in dopolnitvah določenih zakonov na področju kmetijske zemljiške politike, 22 March 2019.

16 Osnutek Zakona o spremembah in dopolnitvah Zakona o kmetijskih zemljišcih, 23 November 2020.
} 


\section{Special legal framework for legal transactions inter vivos}

\subsection{Overview of the rules}

Compliance with special provisions on the legal transfer of agricultural land, forests, and holdings is ensured through extensive administrative control. Namely, the ALA stipulates that the notarial notification of the alienator's signature on the 'land register permission' (registration clause) is not allowed without the approval of the competent administrative body or a decision issued by the same body that the approval of the legal transaction is not necessary according to the statute. ${ }^{17}$ As the notarial notification of the alienator's signature is a condition sine qua non for the transfer of ownership rights on the new acquirer, such provisions contain a very efficient sanction against any violation of the special provisions. ${ }^{18}$

The special legal framework for the transfer of agricultural land, forests, and agricultural holdings through legal transactions inter vivos includes the following: (a) a statutory preemption right of several subjects who enjoy the priority right to purchase agricultural land, forest, or agricultural holdings offered for sale; (b) restrictions on donation contracts; (c) restrictions on physical divisions of certain agricultural land and forest plots; (d) restrictions on establishing new co-ownership shares; (e) restrictions on the division of the protected farms; and ( $f$ ) special rules for agricultural land lease contracts.

\subsection{The statutory priority right to buy agricultural land and holdings}

The priority right to buy agricultural land or agricultural holding is stated in the ALA and may be exercised by certain beneficiaries who may enforce their statutory pre-emption rights in the following order: (1) co-owner(s), (2) farmer(s) whose agricultural land borders on the agricultural land offered for sale; (3) the lessee of the agricultural land offered for sale; (4) another farmer; (5) an agricultural organisation or an individual entrepreneur who needs land or a farm to perform agricultural or forestry activities; and (6) the NALFF for the Republic of Slovenia (Art. 23).

According to the ALA, a farmer is an individual who cultivates agricultural land as its owner, lessee, or user; is adequately qualified for this cultivation; and obtains a significant part of the income (at least $2 / 3$ of the average salary in Slovenia from the past year) from agricultural activity. The status of being a farmer is retained by an individual who cultivated agricultural land and does not carry out agricultural activity any more due to disability or age but manages the land cultivation. An individual who does not carry out agricultural activity yet, but intends to do so, may obtain the status of a farmer by stating before the administrative authority their intent to cultivate the agricultural land on their own or with the help of others, evidence of the necessary

\footnotetext{
17 ALA Art. 19 and 22.

18 According to Art. 49 of the Property Code, "an entry in the land register is required for the acquisition of an ownership right over immovable property through a legal transaction" (the first paragraph), while the "E]ntry in the land register shall be made on the basis of a document containing the land register permission" (the second paragraph).
} 
professional qualifications, and evidence of their future foreseen income from agricultural activity as significant (new entrants, Art. 24 of the ALA).

The ALA prescribes specific procedures for the enforcement of the preemption right. An owner who intends to sell agricultural, forest, or farm must submit their offer to the competent administrative body ('administrative unit') in the area where the agricultural land, forest, or farm is located. By submitting the offer to the administrative unit, the owner is deemed to have authorised the administrative unit to receive a written statement of the acceptance of the offer.

The administrative body must immediately publish the offer on their notice board and the unified state portal of the 'E-government'. The deadline for acceptance of the offer is 30 days from the day when the offer is published on the notice board of the administrative unit. If no one accepts the offer within the time limit, the seller must repeat the offer if they still wish to sell the agricultural land, forest, or farm. If two farmers within the same priority class (for instance, two farmers as neighbours to the agricultural land for sale) enforce their priority rights by accepting the offer, the ALA provides additional rules to determine the buyer.

According to the Forests Act, the State and municipality have preemption right on certain forests with emphasised non-economic functions (protective forests and forests with a special purpose). Notwithstanding these provisions, the Republic of Slovenia or a legal entity managing State forests has the pre-emptive right to purchase forest land with an area over 30 ha (Art. 47(3) of the FA).

The statutory preemption rights on other forests may be enforced by an owner whose land borders a forest that is being sold, and subordinately, by another owner whose forest is the nearest to the forest that is being sold. In these cases, the corresponding provisions on preemption rights from the ALA apply (Art. 47(10), (11) of the FA).

The statutory preemption rights, the object of which may be agricultural land, are also regulated in other pieces of the Slovenian legislation (for example, the Nature Conservation $\mathrm{Act}^{19}$ and the Water $\mathrm{Act}^{20}$ ). The statutory preemption rights, according to other acts, sometimes have a higher priority than the preemption rights according to the ALA. For some sale contracts, the approval of the administrative body is not necessary (for instance, if a sale contract is concluded between spouses or cohabiting partners or between an owner and their intestate heir, which conforms with the statutory provisions (see infra, Section 3.2), or if a sale contract is concluded between all co-owners of agricultural land, a forest or a farm).

According to the literature, the circle of statutory preemptors in the present regulation is too wide, in particular, because 'other farmers' and 'agricultural organisations and individual entrepreneurs' may enforce their priority rights to purchase agricultural land without further requirements that would guarantee the rational use and inclusion of the concerned agricultural land in an existing or a new holding of the preemptor. ${ }^{21}$

19 Zakon o ohranjanju narave 1999, with subsequent amendments.

20 Zakon o vodah 2002, with subsequent amendments.

${ }^{21}$ Rejc 2018, 272-278. He also criticises provisions on recognition of a farmer's status regardless of qualification and the income requirement for farmers who ceased farming activities. 
Otherwise, such preemptors could act as 'strawmen' for the purchase and resale of the agricultural land, which is not the purpose of the statutory preemption rights according to the agricultural land legislation. ${ }^{22}$

The Draft Act 2019 proposed an altered definition of preemptors and their priority order. Namely, (1) co-owner(s) who retained the first place, would be immediately followed by (2) the NALFF, while the successive holders of statutory preemption rights would be farmers, defined neutrally with regard to their legal form. These farmers would be natural or legal persons who manage agricultural holdings and have been registered in the register of agricultural holdings (RAH) for a minimum period of five years. Among these preemptors, the priority would be given to (3) neighbouring farmers (farmers whose land borders the agricultural land for sale), followed by (4) local young farmers (farmers who have, instead of being registered in the RAH for at least five years, received financial support in the last five years from the rural development programme if they comply with the farm size requirements [6-80 ha of comparable agricultural land], are younger than 40 years, and are residents in the municipality where the agricultural land for sale is situated or in a neighbouring municipality), (5) local farmers who manage comparable agricultural land within the same range and are socially insured as farmers, (6) other local farmers, and finally, (7) other farmers registered in the RAH. Sales contracts with buyers who are local farmers meeting the requirements for the fourth and fifth place in the proposed new priority order would be allowed as preemptors without formalities related to the statutory preemption rights.

Compared to the prior version from 2019, the Draft Act from 2020 reserves the first three places for (1) co-owners followed by the local farmers ${ }^{23}$ who are (2) neighbours or (3) a lessee of the agricultural land offered for sale. The next place is reserved for (4) local young farmers managing 5-100 ha of comparable agricultural land, followed by local farmers managing the agriculturral land of the same surface who are (5) socially insured as self employed in agriculture or (6) not (local farmers with farms capable of development). The National Fund has slipped to the last but one (7) place, before (8) other local farmers.

\subsection{Restrictions on donations of agricultural land}

To prevent the statutory preemption rights from the conclusion of donation contracts, the legislation restricts subjects who obtain agricultural land as donees. Potential donees in such transactions may only be: (a) a spouse or cohabiting partner, children, or adopted children, parents or adoptive parents, brothers or sisters, nephews or nieces, and grandchildren of the donor; (b) a donor's son-in-law, daughter-in-law,

However, the income requirement, if applied, could have a discriminatory effect on citizens from certain EU Member States.

22 Ibid. 284.

23 Both draft acts define a local farmer as farmer having a permanent residence (individual) or registered office (leal entity) in the same or a neighbouring municipality in which the agricultural land subject to sale is located. 
or cohabiting partner of a donor's child or adoptive child, provided that they are members of the same farm; (c) a farm holder who has obtained funds from the rural development programme as a young transferee of a farm, if no more than five years have passed since the transfer of the farm; or (d) a local community or the State (Art. 17a(1) of the ALA).

\subsection{Restrictions on the physical division of agricultural land and forest plots}

Among the agricultural operations, the ALA also regulates land consolidation as a procedure through which land within a certain area is assembled and redistributed among the previous owners so that each is allotted land that is territorially compact to the highest extent possible (Art. 55). Land that has not been consolidated can be divided only when the area achieved by the land consolidation does not deteriorate as a result of this division (Art. 75 of the ALA).

The Forests Act provides that land plots that constitute a forest and are smaller than 5 ha may only be divided: (a) if the land-use on such parcels or parts thereof is not specified as forest in spatial planning documents; (b) if the division is necessary due to the construction of public infrastructure; or (c) if they are a subject of joint ownership with the Republic of Slovenia or a local community (Art. 47(6)).

\subsection{Restriction on establishing new co-ownership shares}

The ALA prohibits the creation of new co-ownership shares on agricultural land through donation contracts in favour of a young farmer or sales contracts (Art. 17a(2)). This provision is understandable as new co-ownership shares make the common use of the agricultural land more complex ${ }^{24}$ and increase, in principle, the fragmentation of agricultural land. ${ }^{25}$ The provision also prevents the artificial creation of co-ownership shares with the aim of obtaining statutory preemption rights of the first priority on the entire agricultural land plot.

\footnotetext{
24 According to the Slovenian Property Code, co-owners have the right to jointly manage a co-owned object. Transactions in connection with the regular management of objects require the consent of the co-owners whose undivided shares comprise more than half of its value. Transactions that exceed the scope of regular management include the disposal of the object and determine 'the method of use' and designate 'the manager of the object' and require the consent of all co-owners (Art. 67). To enable the use and cultivation of co-owned agricultural land plots with due diligence, the ALA partly derogated the quoted provision from the Property Code so that the determination of agricultural land user and land-use practices, if an agricultural land plot is co-owned, requires the consent of co-owners whose undivided interest represents more than half of the entire value (Art. 7(2)).

${ }^{25}$ Following the Roman law maxim 'Communio est mater rixarum' (co-ownership is the mother of disputes), a co-owner may not waive their right to the division of a thing for an extended period (Art. 69(2) of the Property Code).
} 


\subsection{Restrictions on the division of protected agricultural holdings (protected farms)}

\subsubsection{Notion of the protected farm}

According to the present legislation, a protected farm is an agricultural or agriforestry economic unit that encompasses agricultural land, forests, agricultural machinery, tools and livestock, farm-related easements, and similar rights, earmarked for agricultural and forestry activities (Article 3 of the IAHA), and must meet two requirements related to its holder(s) and the surface of agricultural land and forests.

The holders of a protected farm can only be individuals. According to the IAHA, a protected farm may belong either to one individual or to two individuals if they are closely linked (through marriage, cohabitation, and partnerships, or lineal relationships) to ensure that the common management of the protected farm by both holders is based on their close relationship. Ownership and other property rights that constitute a protected farm of a married couple may belong to both of them as holders of exclusive entitlements to different objects and/or co-holders (by definite shares) or joint holders (by indefinite, but definable shares) of entitlements to the same objects. A protected farm of ancestor and descendant must belong to both of them as co-holders of property rights (for instance, as co-owners of agricultural land, conf. Art. 2(1) of IAHA).

However, only middle-sized farms are protected, and a protected farm must cover a minimum of at least 5 ha and a maximum of no more than 100 ha of comparable agricultural land.26 Additionally, the present criteria for the determination of protected farms are criticised by legal theory on two grounds.

First, the quantitative criteria only relate to the surface of comparable agricultural land, regardless of other means of production, which are also necessary for a farm as a productive operating unit. ${ }^{27}$ Second, the lower limit for a protected farm is too low and too rigid. Therefore, a protected farm does not always enable its holder to make a living out of agricultural activity, which is not in conformity with the Constitution. The legal theory proposes two alternative solutions: either leave decisions on the protection of farms to the holders or improve the criteria for determination of a protected farm ex officio. ${ }^{28}$ The Draft Act from 2019 opted for the first solution: the farms that satisfy quantitative requirements should be protected on the request of their holder(s). However, this proposal was dropped by the Draft Act of 2020 .

\footnotetext{
26 To make different agricultural land comparable, the IAHA states that 1 ha of the comparable agricultural area is equal to: (a) 1 ha of land that has a land rating (credit rating) from 50 to 100 in accordance with the regulations governing the registration of real estate; (b) 2 ha of land with a credit rating of 1 to 49 , or (c) 8 ha of forest land.

Farms that meet the conditions but mainly consist of forests are protected farms only if they have at least 2 ha of comparable agricultural land registered as agricultural land in the land cadastre (Art. 2(2 and 3) of the IAHA).

${ }^{27}$ Rajgelj 2016, 27.

${ }^{28}$ Drobež 2017, 1457.
} 


\subsubsection{Restrictions on legal transactions dividing protected farms}

Since 1986, the division of protected farms inter vivos has been prohibited in Slovenia. However, the list of exceptions has become more extensive. At present, the division of a protected farm through legal transactions inter vivos is exceptionally permitted in several cases, which can be classified to specific groups.

The first group of exceptions encompasses the alienation of land that is not earmarked for agricultural activity (building land not used for agricultural activities) or is less suitable for agricultural production so that the holder of the protected farm may exceptionally bequeath these land plots through a will to an heir who is entitled to a hereditary share but does not overtake the protected farm. ${ }^{29}$

The second group of exemptions consists of transactions through which the division of a protected farm results in (1) creating or enlarging another protected farm, (2) enlarging and rounding off (but not the creation) of a non-protected farm or agricultural land belonging to an agricultural organisation or individual entrepreneurs so that the overall result of the transaction with the agricultural land structure is not negative in the eyes of the legislator. The Act also allows transfers of agricultural land and other component parts of protected farms to the State or a municipality (Article 18 of the ALA).

Restrictions on the division of protected farms inter vivos seem to be too rigid as they only address single transactions without taking into account that a transaction may be a part of a wider plan for a more rational use of the agricultural land (for instance, a holder of a protected farm sells a plot of land to purchase another similar plot used in a similar way that is of better quality nearby), while casuistic exemptions linked to certain legal types of contracts could open a way to circumvent the statutory preemption rights and restrictions on donation contracts. The restrictions on the division of protected farms may also considerably prolong the sale of agricultural land in compulsory execution procedures.

\subsection{Lease of agricultural land}

The ALA contains several special provisions on the lease of agricultural land relating to statutory pre-lease rights, the content and written form of the lease contract, the minimum lease period, the lessee's duties to cultivate or use land with due diligence, and the rights of lessees to the cash value of unamortised crops after the termination of the contract (depending on whether the investments were made with the consent of the landlord or not).

A lease contract must include land register and land cadastre data on leased land; a description and the unamortised value of the facilities, equipment, and permanent crops; the depreciation period of long-term plantations; the rent amount; the purpose and period of the lease; and a provision as to whether the leasehold right shall be

\footnotetext{
${ }^{29}$ More precisely, these heirs may inherit land or other real estate or movable property if they are not important for the protected farm but only up to the amount of the compulsory share (Art. 15(3) of the IAHA).
} 
inheritable or not. A lease relationship must also be entered in the land register and the land cadastre.

The ALA regulates the priority to take agricultural land, forests, or agricultural holdings on lease. Several persons may exercise these priority rights in the following order of priority: (1) the present lessee (if the contract was not terminated with this person due to breach of duties); (2) a lessee of land bordering the land that is being leased and a farmer who owns the land bordering the land that is being leased; and (3) another farmer, agricultural organisation, or individual entrepreneur who needs the land or the farm to carry out an agricultural activity (Article 27 of the ALA).

The lease period must correspond to the purpose of the use of the leased land (for at least 25 years for the establishment of vineyards, orchards, or hop fields, at least 15 years for the establishment of plantations of fast-growing deciduous trees, and at least ten years for other purposes). A lessor who, after the announcement of a lease offer, is unable to conclude a lease contract for the prescribed minimum or longer period, may offer the agricultural land for lease for a shorter period. Where permanent crops already exist on leased land, a lease relationship may also be concluded for a period necessary for the full amortisation of the lessee's investments in these crops.

The Draft Act from 2019 foresaw new special and more detailed provisions to be inserted into the NALFFA for the lease of state-owned agricultural land. The priority rights to lease state-owned agricultural land would be granted to several persons in the following priority order: (1) local young farmers who received financial support for the takeover of the farm in the past five years and are managing 6-80 ha of comparable agricultural land, (2) local farmers who are compulsorily socially insured on the basis of agricultural activity and manage 6-80 ha of comparable agricultural land, (3) other local farmers, and (4) other farmers.

All special provisions on the lease of agricultural land in the ALA (including the present statutory pre-lease rights) would be abrogated so that the general provisions (the Obligation Code) would apply to lease contracts of non-state-owned agricultural land.

These proposals were strongly criticized by the agricultural companies as the largest lessees of the State-owned agricultural land (see also infra, Section 5). Therefore, they were left out from Draft Act of 2020.

\section{Agricultural land and agricultural holdings in succession law}

\subsection{General succession rules and the inheritance of unprotected farms}

The general succession rules, that is, the Inheritance Act (IA), applies to the inheritance of estates that are not protected farms (including unprotected farms). Some special rules, contained by the Inheritance of Agricultural Holdings Act (IAHA) apply to the inheritance of protected farms. As far as the special rules do not regulate the succession of protected farms, general succession rules are applicable. At several points, the IAHA refers to certain provisions of the IA. 
Franci Avsec

Legal Framework of Agricultural Land/

Holding Succession and Acquisition in Slovenia
Journal of Agricultural and

Environmental Law

$30 / 2021$

The inheritance of protected farms and other estates is based on several universally applicable principles. One of these principles concerns the basis for succession: the inheritance of the estate is based on the will (testamentary succession), or, if the will was not made or is not valid, on the law (intestate succession).

In Slovenian succession law, men, women, and children born in or outside marriage have equal inheritance rights (Article 4 of the IA). As the adoption of a child produces an equal legal relationship between the adopted child and the adoptive parents, adopted children have the same succession right vis-a-vis their adoptive parents as natural children (and vice-versa, Article 10 of the IA).

The deceased's partner in cohabitation (long-term domestic community of a man and a woman, who are not married, if there are no reasons for a marriage between them to be invalid), as well as the deceased's partner in a registered or an informal civil union, have the same rights of succession as a deceased's spouse (Article 11 of the IA, Articles 2 and 3 of the Civil Union Act, CUA). ${ }^{30}$

The intestate heirs are classified into three succession orders. The intestate heirs of a lower succession order exclude intestate heirs from a higher succession order from inheritance. Intestate heirs of the first succession order are the deceased's spouse and descendants who inherit equal shares. ${ }^{31}$ If a child or adopted child died before the deceased, their children and adoptive children (grandchildren of the deceased) step in the place of their parents and inherit their parent's share in equal shares, and so forth (ius representationis, the right of representation).

Intestate heirs of the second succession order would be the deceased's spouse and the deceased's parents who inherit the estate if the deceased did not leave any descendants (natural and adoptive children or grandchildren). The spouse inherits one half of the estate, and the parents inherit the other half. If the deceased left neither parents nor descendants, the spouse inherits the entire estate. If the spouse died before the deceased, the entire estate is inherited by the deceased's parents. When one or both parents died before the deceased, the estate is inherited by the descendants of the deceased parent(s).

The heirs of the third (last) succession order would be grandparents of the deceased and their descendants who inherit the estate if the deceased left no spouse, descendants, parents, or descendants of parents. According to the law, the grandfather and grandmother on the father's side, as well as the grandfather and grandmother on the mother's side, inherit one half (each one of them one quarter) of the estate. If one of the grandparents from the father's or the mother's side died before the deceased, their share is inherited by their descendants by the right of representation.

\footnotetext{
30 Zakon o partnerski zvezi 2016.

31 The Act also permits certain departures from the principle of equal share. On the request of the deceased's spouse or descendant who does not have the necessary means for sustaining a livelihood and inherits along with other heirs of the first succession order, the court may, at the request of such an heir, decide that the requesting heir also inherits a part of the share of the estate that would be, according to the law, inherited by the co-heirs. The deceased's spouse or descendant may request an increase in their share of the inheritance against all or individual co-heirs. The court may decide that the requesting heir inherits the entire estate if the value of the estate is so small that this heir would suffer hardship if it were divided (Art. 13 of the IA).
} 
Where there are no descendants of one grandparent, the share of the deceased grandparent falls to the other grandparent. If both grandparents from one side died before the deceased without leaving descendants, the grandparents from the other side or their descendants would inherit the estate alone.

Each intestate heir is credited with what they receive as a gift from the deceased unless the deceased stated at the time of the gift or later, or in the will that the gift should not be included in the hereditary share; or if it can be concluded from the circumstances that it was the will of the deceased (Article 46 of the IA). The testamentary succession has priority before the intestate succession. However, the freedom of the testator to dispose of the estate is restricted by provisions according to which some persons who are very close to the deceased (the forced heirs) have the right to a certain part of the estate (compulsory share). In Slovenian general succession law, forced heirs are the deceased's spouse, children, adopted children and their descendants, parents, grandparents, brothers, and sisters, if they are entitled to inherit according to their succession order. Additionally, grandparents, brothers, and sisters of the deceased are forced heirs under additional conditions: if they are permanently incapable of work and do not have the necessary means of subsistence (Article 25 of the IA).

The compulsory share for the descendants, adoptees, and their descendants and the spouse is one-half, while the compulsory share for the other forced heirs is onethird of the share that would go to each of them according to the rules on intestacy succession (Article 26 of IA). The IA prescribes special rules on how the value of the estate is calculated to establish the value of the compulsory share. From the estimated value of the property that the testator had at the time of their death (including the property disposed of by the will and all claims of the testator, except manifestly uncollectible claims), the costs for the inventory and estimation of the estate and the testator's funeral are deducted. The difference is increased by the value of gifts given by the testator in any way to intestate heirs who would inherit from the deceased and the value of gifts given by the testator in the last year before their death.

If the compulsory share is deprived, testamentary dispositions are reduced proportionally as much as necessary to supplement the compulsory share. If the compulsory share is not yet covered, the gifts are returned in the reverse chronological order in which they were given (Articles 35 and 38 of the IA). Through their will, the testator may give a material benefit to another person without appointing this person as an heir (legacy).

The Inheritance Act exhaustively lists grounds on which a testator may deprive a forced heir of their compulsory share (disinheritance, Article 42 of the IA) as well as grounds on which any person is ex lege unworthy to inherit on the basis of the Act or a will or to obtain anything according to the will (unworthiness of inheritance, Article 126 of the IA).

\section{Acquisition ownership of agricultural land or holding by a legal person}

In the period before the transition, when social ownership was the prevailing ownership form in the economic system (except in agriculture and forestry), the agricultural land legislation first introduced the statutory priority rights of socially 
owned agricultural organisations (enterprises) to purchase and lease privately owned agricultural land. In 1973, the first Slovenian Agricultural Land Act recognised the statutory preemption and pre-lease right to farmers, who were placed behind agricultural organisations and before citizens who were not deemed to be farmers (non-farmers).

In 1990, the amendments to the ALA reversed the priority order so that farmers obtained better statutory preemption and pre-lease rights compared to agricultural organisations, while the statutory preemption and pre-lease rights were extended from private to all agricultural land.

During the ownership transformation of social enterprises, agricultural land and forests were excluded from the privatisation of agricultural and forestry enterprises. ${ }^{32}$ They were transferred to the State and have since been managed by the NALFF. Agricultural and forestry enterprises could continue their activities by leasing previously socially owned, and then state-owned, agricultural land or concluding concession contracts (forests), if the land was not an object of denationalisation (restitution to the former owner(s) or their heirs).

According to the Draft Act of 2019, the lease contract of state-owned land would be for at least ten years and could be prolonged for the same period unless the lessee notified the National Fund that they are not interested in prolongation. However, the proposed provisions from the Draft Act of 2019 would mostly affect the position of legal persons as lessees of the National Fund. These provisions related to (a) the maximum state-owned agricultural land (100 ha) that may be leased to one natural or legal person, (b) the gradual, but progressive adaptation (decrease) of the agricultural land area that was leased to lessees who exceed the maximum lease area (through future successive lease periods) until the upper limit of 100 ha is achieved, (c) the exclusion of the lease period prolongation in cases where the ownership structure of a legal person has been changed with regard to more than a 50-per cent share(s), and (d) the obligation of larger lessees taking on leases of more than 5 ha of comparable agricultural land to submit a plan for agricultural holding development. It was proposed that in cases where the plan would not be submitted, or the lessee would not comply with the commitments, the lease contract would not be prolonged.

These proposals unleashed a controversial discussion. Some studies have criticised the proposed provisions as an ungrounded and unconstitutional encroachment on the legitimate expectations of legal persons that are large lessees of the National Fund, which, if adopted, would have negative consequences for rational agricultural production and food security in Slovenia, contrary to the general interest. ${ }^{33}$

Due to diverging standpoints about these proposals, the Draft Act of 2020 does not foresee any amendments of the present regulation relating to state-owned agricultural land leases.

The abuses related to the acquisition of agricultural land by legal persons are limited due to strict provisions on the registration of nearly all users of agricultural land.

\footnotetext{
32 Zakon o lastninskem preoblikovanju podjetij (Ownership Transformation of Companies Act) 1992, with subsequent amendments, Art. 5.

${ }^{33}$ Korže 2019, 1437.
} 
According to the Agriculture Act, ${ }^{34}$ individuals or legal persons who are either obliged to be entered into the Ministry of Agriculture, Forestry, and Food records according to special regulations (for seed material, for instance); or who are using at least 0.1 ha of olive groves, 0.2 ha of strawberry plots or hop gardens (regardless of its size), or 1 ha of other agricultural land; who sell agricultural products; or submit an application for agricultural policy subsidies, must be entered in the register of agricultural holdings. The chain of owners must be followed by publicly accessible data on the beneficial ownership of legal persons set up by the business register according to the Slovenian Prevention of Money Laundering and Terrorist Financing Act. 35

\section{Conclusion}

It is difficult to assess the effectiveness and efficiency of the Slovenian special provisions on the legal transfer of agricultural land. First, the production factors, in particular the land, are less mobile in agriculture than in other sectors. However, extensive special regulations also contribute to a slower pace of legal transfers. Expectations that administrative restrictions alone can improve agricultural land and holdings structures are unfounded. They can only prevent or at least curb undesirable changes. Due to various circumstances in life situations, the restrictions are not absolute but must allow some exceptions.

Considering these limitations, a very dense and complex regulation of the legal transfer of agricultural land and holdings in Slovenia seems to have shortcomings that need to be rectified.

First, the special regulation seems to be too narrow because it only tackles transactions resulting in the transfer of ownership rights and agricultural land lease contracts, leaving some important rights for use agricultural land (such as usufruct) out of the scope of this regulation.

However, simultaneously, the special regulation seems to be too extensive, as far as it provides special provisions on certain types of contracts. Namely, the participants in obligation relationships are free to shape their contracts and may also conclude mixed and compound contracts and even contracts that are not foreseen in the Obligation Code (innominate contracts). Various contracts may include the same economic and social goals and have the same consequences for agricultural land structures.

Despite the comprehensive administrative control of agricultural land and agricultural holding transactions, very few statistical data are available on these transfers. The Draft Act of 2020 introduces some improvements in maintaining updated records and collecting statistical data in this field.

The amendments to the ALA that are proposed in the Draft Act of 2020 introduce important substantial and terminological changes. The definition of farmer in the ALA originates from a period when an individual having such a status was allowed to own larger surface and better quality of agricultural land and forests than

\footnotetext{
34 Zakon o kmetijstvu 2008, with subsequent amendments.

35 Zakon o preprečevanju pranja denarja in financiranja terorizma 2016, with subsequent amendments, Art. 41.
} 
other individuals (non-farmers). After the abolishment of the agricultural land maximum in 1992, the status of farmer became important for the preemption right and tax exemptions linked to agricultural land purchase and some other transactions. The common agricultural policy denotes a farmer in a wider meaning, namely as an individual or a legal person managing unit(s) for agricultural activity. ${ }^{36}$

The current ALA regulates, inter alia, donation contracts in favour of young farmers who obtained financial support to take over farms, thus referring explicitly to the common agricultural policy. The Draft Act of 2020 defines certain categories of statutory preemptors following the notion of farmer within the common agricultural policy. The proposed provisions on preemption rights in the Draft Act of 2020 which place local farmers who meet certain requirements before the National Fund which is followed by non-local farmers, obviously lean on the Interpretative Communication of the European Commisssion. ${ }^{37}$

These provisions demonstrate a convergence between the agricultural land legislation and the common agricultural policy. The advantage of this process is the synergy between administrative restrictions and policy incentives, while too frequent changes of the policy may prove to be its shortcoming.

Another substantial change in the Draft Act of 2020 is cancellation of prohibition to divide protected farms inter vivos. If such proposal is enacted, the protection of these farms against division mortis causa will actually, to a great extent, depend on the will of the protected farm holder(s) because certain legal transactions inter vivos could result in the loss of the protected farm status.

36 See, for instance, Article 4(1)(a) of Regulation (EU) No 1307/2013 of the European Parliament and of the Council of 17 December 2013 establishing rules for direct payments to farmers under support schemes within the framework of the common agricultural policy and repealing Council Regulation (EC) No 637/2008 and Council Regulation (EC) No 73/2009, with subsequent amendments.

${ }^{37}$ Commission Interpretative Communication on the Acquisition of Farmland and European Union Law (2017/C 350/05). The Communication stresses that privileges for local acquireres, to be compatible with free movement of capital principles, "bave to pursue, in a proportionate manner, legitimate objectives in the public interest" what "could be the case if pre-emption rights are granted to local farmers to address land ownership fragmentation, for instance, or if other special rights are given to locals to accommodate concerns resulting from their geographical situation (for example, less developed regions)" (cursive added). 
Franci Avsec

Legal Framework of Agricultural Land/

Holding Succession and Acquisition in Slovenia
Journal of Agricultural and

Environmental Law

$30 / 2021$

\section{Bibliography}

1. Drobež E (2017) Opredelitev zaščitene kmetije za namene dedovanja, Podjetje in delo, 43(8), pp. 1442-1458.

2. Korže B (2019) Ustavnost predlaganih sprememb in dopolnitev veljavne ureditve o podaljševanju pogodbenih razmerij z zakupniki kmetijskih zemljišč, Podjetje in delo, 45(8), pp. 1437-1449.

3. Rajgelj K (2016) Ali je mogoče zaščiti kmetijo, ki to ni, Odvetnik, 18(1), pp. 24-27.

4. Rejc Z. (2018) Promet s kmetijskimi zemljišči, Podjetje in delo, 44(2), pp. 255-295.

5. Zupančič K (2005) Dedovanje z uvodnimi pojasnili, Uradni list Republike Slovenije, Ljubljana.

6. Zupančič K \& Žnidaršič Skubic V (2009) Dedno pravo, Uradni list Republike Slovenije, Ljubljana. 